\title{
Assessing Transaction Environment Conditions for Investment and Construction
}

\author{
Marina Mishlanova ${ }^{1, *}$ and Vadim Kharitonov ${ }^{2}$ \\ ${ }^{1}$ Moscow State University of Civil Engineering, 129337, Yaroslavskoye Shosse 26, Moscow, Russia \\ ${ }^{2}$ ANPO NGS-Orgproyektekonomika, 115172, ul. Narodnaya, Building 4, Moscow, Russya
}

\begin{abstract}
This paper contains characteristic description of the transactionbased approach and identifies problems of studying the transaction environment for investments and construction. It also discusses the results of transaction cost analysis in the real estate sector, and assessment of the business environment in Russia. The authors present indirect assessment of transaction environment through the economic freedom index, detailed particularly for Russia; they demonstrate the transaction environment structure and offer methodological recommendations on evaluation of transaction environment for investment and construction.
\end{abstract}

\section{Introduction}

Evolution and the modeling of any socio-economic system as a phenomenon can be regarded through the following basic elements: sanctions, operations and transactions [1]. The phenomenon of transactions holds a significant position in the modern theory and practice of management, in the theory of databases and software engineering. The definitional basis of the "transaction" category requires at least a logically meaningful operation that makes sense and could be effected only in entirety. In these terms, the economic definition of a transaction assumes a deal executed to meet the parties' requirements and encumbered with reciprocal concessions. The information definition of a transaction understands a whole group of logically united sequential steps used to process data. An integrated approach considers a transaction in broad sense as a series of activities to exchange commodities, information being one of such.

Each transacting player has their own status agreed with the other players. Acting jointly, the players maintain a certain condition of their shared field of relations, as this corresponds to some distributed mutually accepted capabilities and limitations. The phenomenon of transaction represents coordinated transition of economic relations to a new status, which generally moves the entire system to a new state [2]. A set of various arguments helps to consider some individual, complex and systemic transactions as a subsystem in the investment and construction sector, as an involved composition of functional and non-functional requirements, restrictions and controls. In terms of the systemic approach, a significant role in implementation of transactions is played by the environment that creates conditions for long-term stable interactions, enables implementation of compensatoryrestorable transac-

*Corresponding author: mishlanova_m@mail.ru 
tions, allows use of alternative transactions, shapes conditions for monitoring and auditing, and guarantees security of transactions [3].

\section{Principal Section}

The main reason for focusing on the environment in which economic activities are pursued is that transaction costs tend to grow against the total gross domestic product [4].This problem is relevant for investments and construction because total transaction costs can reach up to $70-200 \%$ of construction projects costs [5etc.]. According to research by Center for Strategic Research Fund, evolution of the housing market is constrained by high transaction costs that exist in the housing market and mortgage loans [6]. Vertically integrated construction companies register transaction costs of $50 \%$ of other costs and $30 \%$ of total sales [7]. These factors obstruct growth of investment and construction activities.

According to Global Property Guidenational consultants [8], Russia is the European leader in transaction costs of real property sales. To quote Global Property Guide, such costs account for $20 \%$ to $25.5 \%$ of the ultimate value of the property in the long term (see Fig. 1). This includes: agency fees - about $2-5 \%$, legal fees $-0.7-1 \%$, registration costs $0.01-1 \%$, and taxes - $18 \%$.

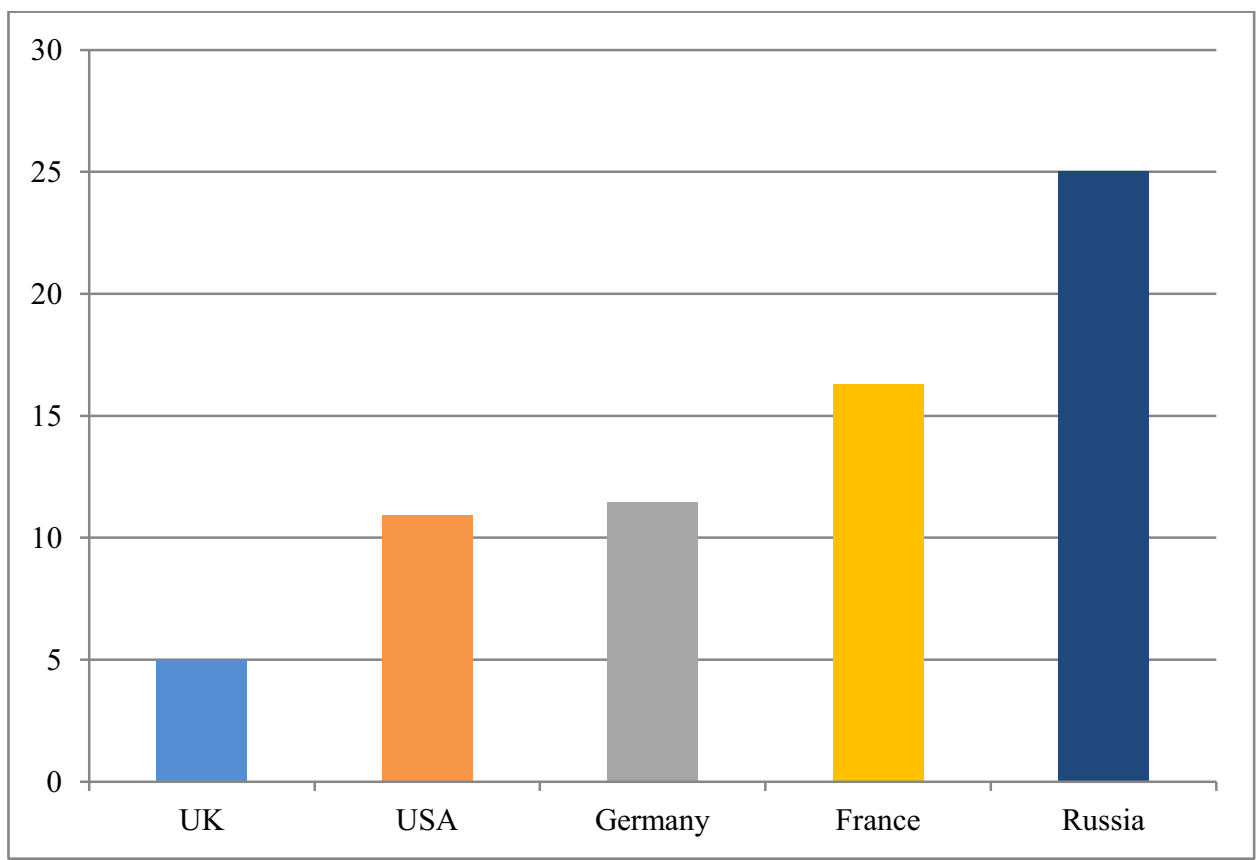

Fig.1. Share of transaction costs in real property sales

The transactional environment for investment and construction includes components of commercial and institutional nature. Business environment is the economic player's immediate surrounding, it reflects direct influences and interactions. Therefore, one can use the business environment index as one of the evaluation components to evaluate the condition of the transactional environment [9]. To generate the index, we use seven indexing sections: product market, logistics and infrastructure, B2B, B2G, financial markets, individual assessment of business climate, investment and social activity [10]. 
The economic crisis in Russia has affected assessment of business environment [9]. Late in 2014, all index indicators dropped and the decline continued in January 2015, when the composite index reached its historic low of 34.1. The annual average business climate index coasted down to 41.7 in 2015 from 44.5 in 2014, thus entering the negative value area.

The index of business climate individual assessment represents subjective attitude of business players to the domestic economic situation and business environment; this is in clear correlation with the transactional environment. The indicator is highly sensitive to both economic and non-economic factors. Throughout the year of 2015, the index of business climate individual assessment stayed in the negative assessment area. The annual mean of the index was 31.9 , or 1.8 points below the 2014 figure. It is the first time the index drops so low since 2012 ever since the Russian Union of Industrialists and Entrepreneurs (RUIE) started its survey polls on business climate in Russia.

In 2016, the Russian Union of Industrialists and Entrepreneurs polled businesses again, and the results are presented in Table 1. The composite index of business climate was 46.9 in September 2016.

Table 1. 2016 Business Environment Index by RUIE

\begin{tabular}{|l|c|c|c|}
\hline \multicolumn{1}{|c|}{$\begin{array}{c}\text { RUIE Business Environment Index } \\
\text { Components }\end{array}$} & July & August & September \\
\hline Product market index & 44.6 & 46.7 & 44.6 \\
\hline Logistics and infrastructure index & 44.3 & 48 & 46.4 \\
\hline B2B index & 47.8 & 46.4 & 46.9 \\
\hline B2G index & 45.6 & 47.9 & 48.6 \\
\hline Material markets index & 44.4 & 43.5 & 46.2 \\
\hline Business climate individual assessment index & 45.2 & 41.1 & 45.3 \\
\hline Investment and social activity index & 55.6 & 48.3 & 50.2 \\
\hline Business environment index & 46.8 & 46 & 46.9 \\
\hline
\end{tabular}

The transaction environment can be assessed indirectly with the economic freedom index on the scale of 100 [11] covering four segments: supremacy of law (categories: rights of ownership and corruption level); constraints on government (categories: fiscal freedom and government spending); regulatory efficiency (categories: freedom of enterprise or business, freedom of employment, monetary freedom); and market openness (categories: freedom of trade, freedom of investment, and financial freedom). According to the research, during late 2014 to early 2015, based on retrospective data in certain cases (see Fig. 2), Europe had five "essentially unfree" nations (Croatia, Bosnia and Herzegovina, Moldova, Greece and Russia). Russia ranked 153 (on the list of 178) on the global rating, bordering on "repressed economy". The reason for concern was the growing trend in the categories "rule of law", "freedom of employment", and "freedom of investment". The researchers registered irregular nature of market reforms, growing inflationary pressure, capital outflow, corrupt government institutions, red tape handicaps for business, and some other negative factors. For details about the economic freedom index in Russia, see Fig. 3. 


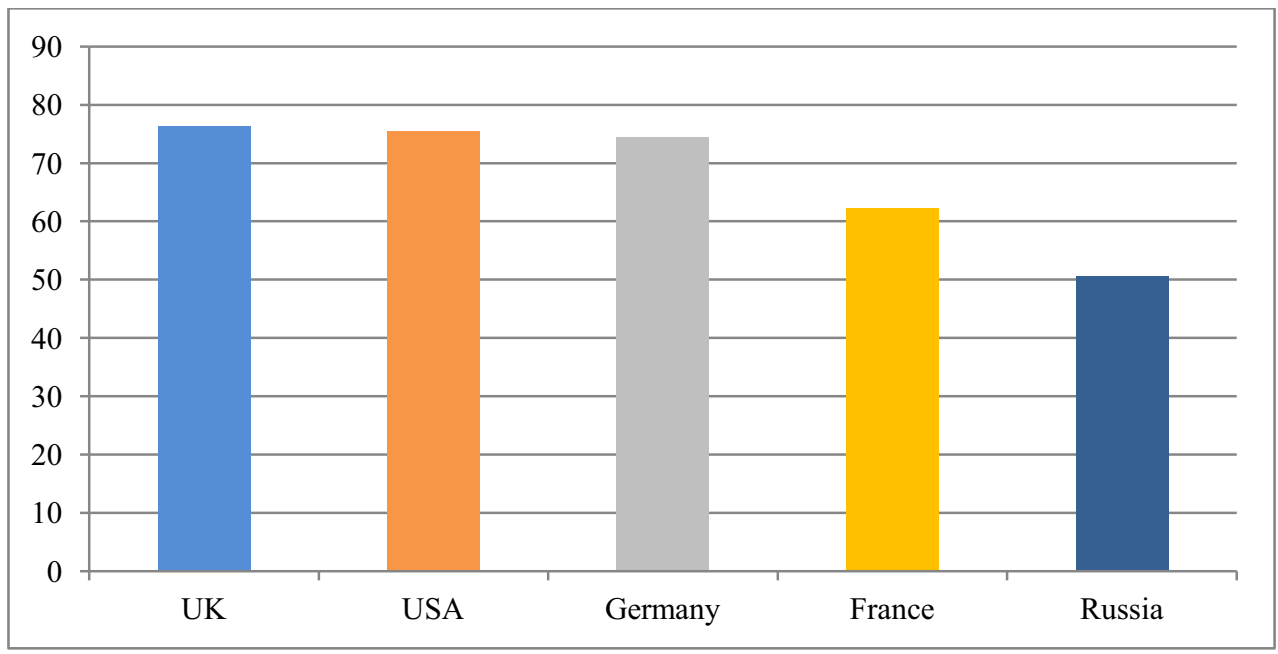

Fig. 2. Economic freedom index

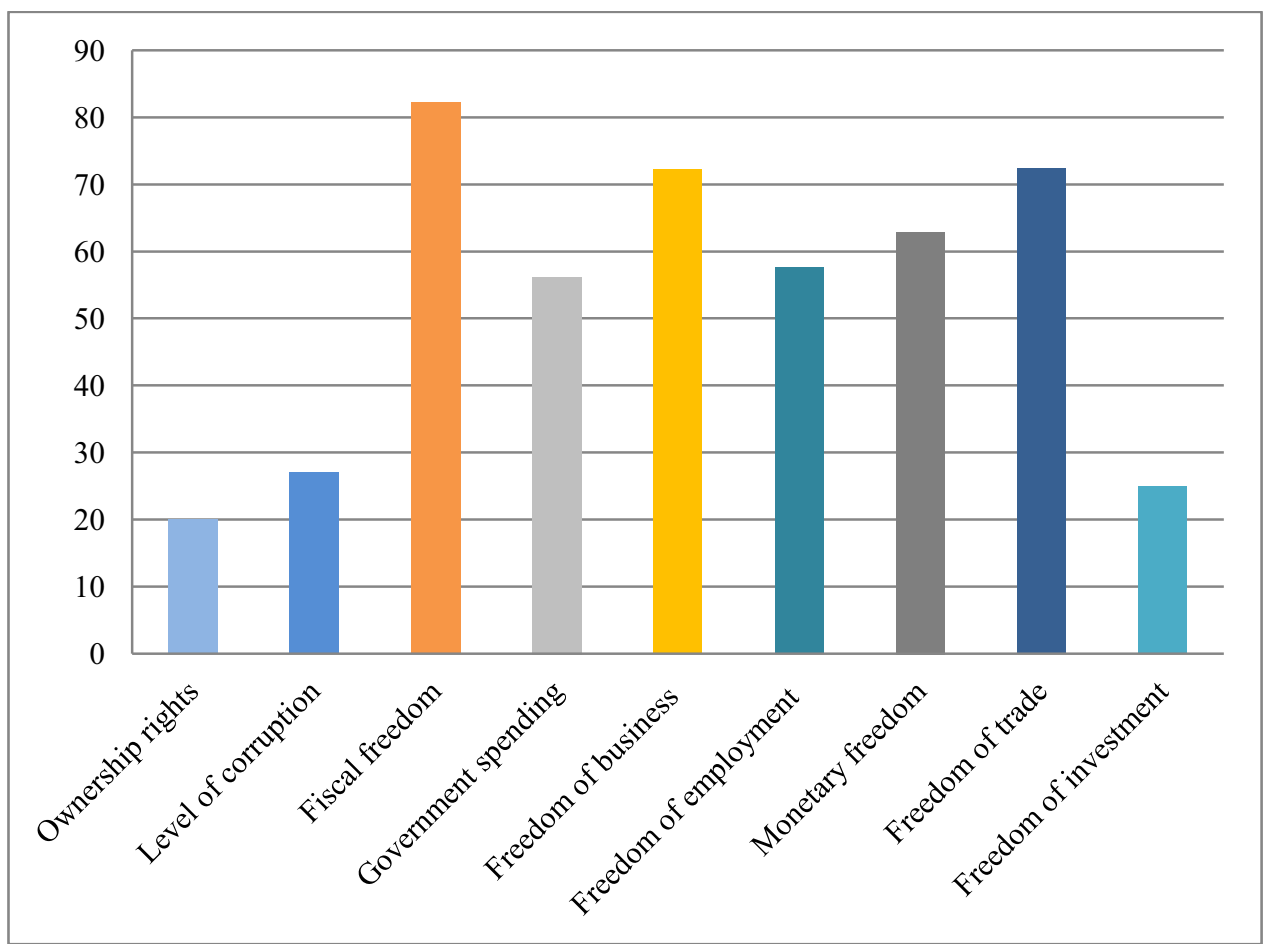

Fig. 3. Details on Economic Freedom Index in Russia

A sub-component of the Economic Freedom Index beyond all doubt is the ownership rights index (Fig. 4) that assumes assessment of the legislative and political environment (categories: independence and impartiality of courts, rule of law, political stability, level of corruption); rights to physical property (categories: protection of physical property rights, property registration, accessibility of loans); intellectual property rights (categories: protection of intellectual property rights, protection of patent rights, level of piracy) [12]. 


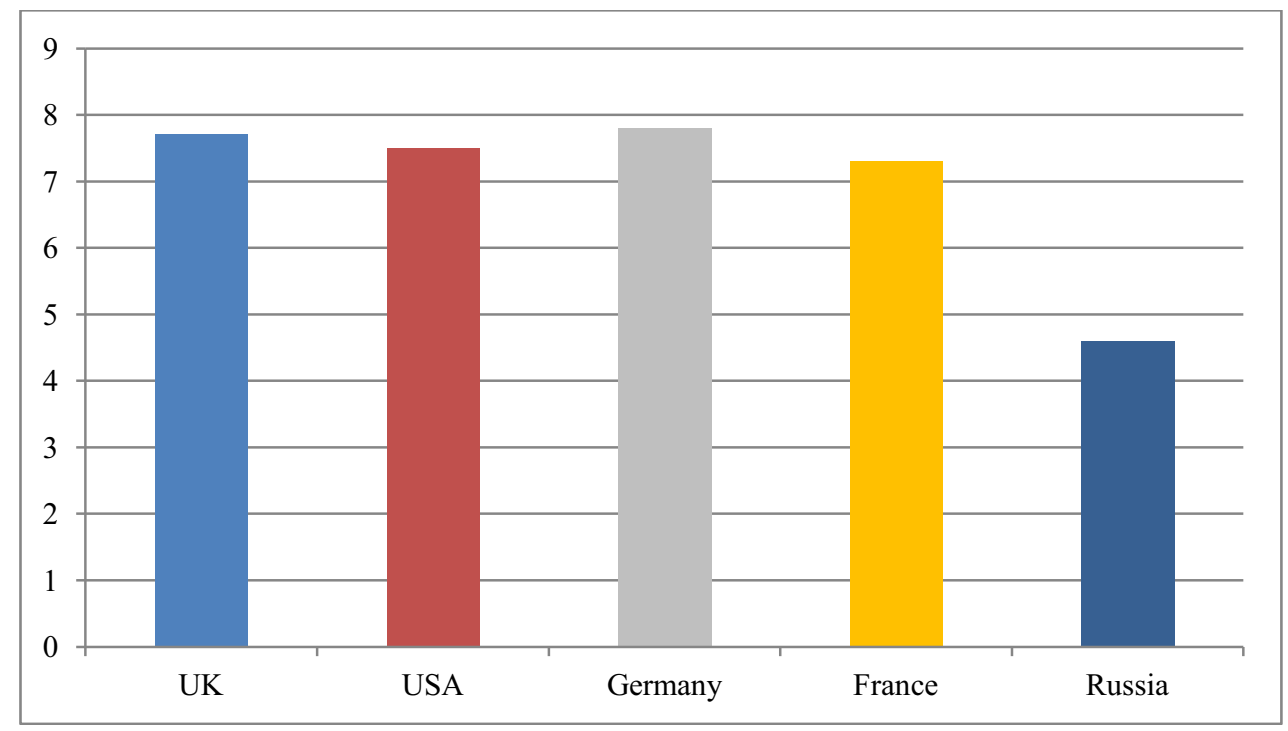

Fig. 4. Property Rights Index

Indirect assessment of the transaction environment can be shifted towards assessment of the economic entities' interests; to do so, we suggest that the indexes of business confidence and business expectations be taken into account. The business confidence index (RF Statistics Board, Center for Economic Analysis under RF Government) for construction is found as the arithmetic mean of balances of the actual order portfolio and the expected change in the number of employees in the companies. The index can be amended with results of other methods. The Finance market index CIF is computed based on indicator dynamics: investments in fixed assets, the share of businesses with "satisfactory" financial condition, order portfolio index (supply) etc. The business expectations index (Russian Economic Barometer) includes the results of polling among businesses, and finds the ratio of the share of businesses who expect higher resource prices, to businesses who expect higher product prices; the ratio of the share of businesses who expect higher product prices, to those who expect higher employment pay rates; the share of businesses who expect increase in production output; the share of businesses who expect new jobs; the share of businesses who expect increase in equipment costs; the share of businesses who expect increase in the portfolio [13].

Issues of assessment and control of transaction environment are examined respective to specific sectors and complexes; this is caused by different structure of transactions, and consequently by different approaches to research them. To validate the substance of transactional environment for investment and construction in the economic space, let us perform actual structuring. As our premises, let us assume that transaction means social interaction that results in transfer or appropriation of ownership rights and privileges in respect of certain resources, intermediate and ultimate construction products. We assume also that in the course of this interaction, the actor of investment and construction will adapt their activities to changing system conditions and quantitatively maximize their well-being.

Transactions in investment and construction based on their subject can be represented in this way: information support, negotiations, contracting, prevention of opportunistic behavior, warranty support, support to production processes, assurance of construction product quality, specification and protection of property rights. Having examined the works of John Commons [14 et al.] we can distinguish three main types of transactions by areas and levels 
of interaction, which we have to slightly alter in order to achieve the objectives of our research:

- commercial transaction (contract) - horizontal type of symmetrical relations, occurring in the sphere of market relations;

- control transaction (intra-system) - vertical type of asymmetrical relations, occuring in the sphere of system hierarchy;

- rationing transaction (external to system) - diagonal type of asymmetric relations, occurring the sphere of rights specifications authority.

The transaction types listed above position various relationships as vectors arranged in a certain way in some part of the economic space - in the transaction environment has its unique coordinates. Such approach lays down the principles of economic modeling in respect of control and optimization of transaction environment, as it helps to visualize the interaction processes. Analysis of structured factors of investment and construction activities [13] suggests the following axes for the part of economic space in question: political determinants - business determinants - investment determinants. To work out a methodology for evaluation of the transaction environment for investment and construction, in the first approximation one can propose the following factor structure of putative coordinate determinants.

Political factors:

- level of political stability (overall political situation, political events, public order, institutional environment, target programs);

- a set of legislated rules to govern economic relations (elaboration of the regulatory framework, relevance of amendments, legal compliance);

- taxation system (acceptability, extent of tax burden, relevance of amendments, system of benefits, activities of tax authority);

- relation of the authorities and society with business (administrative climate, degree of business support, level of corruption, government-business interaction).

Investment climate:

- ability to attract investors (extent of financial systemdevelopment, investorappeal);

- protection of investors and lenders to minimize risk of lost income/investment (investment stability, investment risk);

- efficient investment processes (effective demand for investments or capital intensity, investment activity, investment efficiency);

- available credit for businesses (requirements to borrowers, procedures, loan terms);

- available internal sources of investment (actual depreciation and profits);

- advanced mortgage loans (requirements to borrowers, procedures, loan terms).

Business environment:

- incorporation procedure (costs, number of steps, time limits);

- construction permits (costs, number of steps, time limits);

- connection to power grid (costs, number of steps, time limits);

- registration of title (costs, number of steps, time limits);

- business activity (working capital turnover, payback of core business activities);

- development of business community (business confidence, business ethics, access to information, transparent business processes, in particular, tendering processes);

- enforcement of contracts and payments (intervals and timing of payment delays, insolvency, settlements).

\section{Conclusion}

The results of assessment of the business environment, economic freedom and property rights presented herein can be regarded as fragmented components of the transactional en- 
vironment assessment for investment and construction. In addition, the authors suggest that indexes of business confidence and business expectations should be used to achieve the objectives of the study. The inductive logic underlying this paper leads to methodologically general provisions that are at the same time specific for investment and construction activities. The proposed coordinate determinantsshould become the basis of assessment of transactional environment for investment and construction. The writers represent their vision of the transaction environment that brings close together the information and economic contents of the category of "transaction" and enables methodological transition to economic modeling through assessment of transaction environment for investment and construction.

\section{References}

1. A.A. Piskunov, A.V. Suvorov, Software and Systems 1 (113), 96-100 (2016)

2. I.V. Artamonov, Business Informatics 2 (20), 29-34 (2012)

3. A.A. Afanasev, V.F. Kasyanov, I.G. Lukmanova, D.N. Silka, International Journal of Economics and Financial Issues 5 (3S), 121-124 (2015)

4. J.J. Wallis, C.N. Douglass, University of Chicago Press, 1870-1970 (1986)

5. A.N. Asaul, S.N. Ivanov, IPEV (2008)

6. S.N. Ivanov,Bulletin of Civil Engineers 3 (12), 82-88 (2007)

7. M.Yu. Lukichev, Transaction costs management for building contractors (Moscow, 2011)

8. http://www.globalpropertyguide.com

9. http://pспп.pф

10. A.Mottaeva, MATEC Web of Conferences 1, 73 (2016) DOI: 1051/matecconf/20167307020

11. http://www.heritage.org

12. http://www.internationalpropertyrightsindex.org

13. M.Yu. Mishlanova, Economics and Business 1 (54), 745-749 (2015)

14. J.R. Commons, Terra economicus 10 (3), 69-76 (2012)

15. A.D. Ishkov, M.Yu. Mishlanova, K.P. Grabovyi, International Journal of Applied Engineering Research 11 (3), 1676-1679 (2016) 